\title{
Effect of the Precipitated Phases on Corrosion Behavior of Mg- Y-Nd Ternary Alloy
}

\author{
Quantong Jiang ${ }^{1 *}$, Xia Zhao ${ }^{1}$, Kui Zhang ${ }^{2}$, Xinggang Li $^{2}$, Jie Zhang ${ }^{1}$, Baorong Hou ${ }^{1}$ \\ ${ }^{1}$ Marine Corrosion and Protection Centre, Institute of Oceanology, Chinese Academy of Sciences, No. \\ 7 Nanhai Road, Qingdao 266071, China) \\ ${ }^{2}$ State Key Lab for Non-ferrous Metals and Process, General Research Institute for Non-ferrous \\ Metals, Beijing 100088, China) \\ *E-mail: jiangquantong@qdio.ac.cn
}

doi: $10.20964 / 2017.11 .14$

Received: 10 July 2017 / Accepted: 25 August 2017 / Published: 12 October 2017

\begin{abstract}
Mg-5Y-xNd alloys ( $\mathrm{x}=0.5,1.0,1.5$ wt.\%) were investigated to reveal the influence of precipitated phase on corrosion resistance. The microstructure, precipitated phases and corrosion behaviors of different samples were analyzed by scanning electron microscope, energy dispersive spectrometer and $\mathrm{X}$-Ray Diffraction. The volume fraction of the $\mathrm{Mg}_{12}(\mathrm{Y}, \mathrm{Nd})$ phase increased, whereas that of the $\mathrm{Mg}_{3}(\mathrm{Y}, \mathrm{Nd})$ phase decreased with increasing Nd-content. The weight loss rate decreased from 10.9584 $\mathrm{mg} \cdot \mathrm{cm}^{-2} \cdot \mathrm{d}^{-1}\left(23.0126 \mathrm{~mm} \cdot \mathrm{y}^{-1}\right)$ to $6.2184 \mathrm{mg} \cdot \mathrm{cm}^{-2} \cdot \mathrm{d}^{-1}\left(13.0586 \mathrm{~mm} \cdot \mathrm{y}^{-1}\right)$. The open circuit potential, potentiodynamic polarization curve, electrochemical impedance spectroscope and scanning kelvin probe confirmed that the corrosion rates of $\mathrm{Mg}-5 \mathrm{Y}-\mathrm{xNd}$ alloys follow the order $\mathrm{Mg}-5 \mathrm{Y}-0.5 \mathrm{Nd}>\mathrm{Mg}-$ $5 \mathrm{Y}-1.0 \mathrm{Nd}>\mathrm{Mg}-5 \mathrm{Y}-1.5 \mathrm{Nd}$. This phenomenon occurred because the $\mathrm{Mg}_{3}(\mathrm{Y}, \mathrm{Nd})$ precipitated phase with a face-centered cubic lattice had a more positive potential than the $\operatorname{Mg}_{12}(\mathrm{Y}, \mathrm{Nd})$ phase with an orthorhombic lattice. Thus, the $\mathrm{Mg}_{3}(\mathrm{Y}, \mathrm{Nd})$ precipitated phase acted as the cathode of the electrochemical reaction, and accelerated the corrosion of the $\mathrm{Mg}$ matrix more effectively than the $\mathrm{Mg}_{12}(\mathrm{Y}, \mathrm{Nd})$ phase.
\end{abstract}

Keywords: Mg-Y-Nd alloy; Microstructure; Precipitated phase; corrosion resistance; Electrochemistry

\section{$\underline{\text { FULL TEXT }}$}

(C) 2017 The Authors. Published by ESG (www.electrochemsci.org). This article is an open access article distributed under the terms and conditions of the Creative Commons Attribution license (http://creativecommons.org/licenses/by/4.0/). 